\title{
JUDICIAL TREATMENT OF "CAPITAL" ASSETS ACQUIRED FOR BUSINESS: THE NEW CRITERION*
}

The Internal Revenue Code has created a distinction between the gain or loss resulting from the sale or exchange of a "capital" asset and the net profit which a taxpayer earns by carrying on his trade or business. ${ }^{1}$ Section 1221 initially defines a capital asset as all "property held by the taxpayer (whether or not connected with his trade or business )...."2 This generic definition is qualified by a series of exclusionary clauses. These clauses now cover almost every type of property held by a taxpayer in connection with his trade or business, including: real or depreciable property used in trade or business, ${ }^{3}$ stock in trade, inventory and property held primarily for sale to customers in the ordinary course of trade or business. ${ }^{*}$ But stocks, bonds and similar nondepreciable

*Corn Products Refining Co. v. Commissioner, 350 U.S. 46 (1955).

1. An individual's "ordinary" income is taxed at progressive rates rising to $91 \%$ of the excess over $\$ 200,000$. INT. Rev. CODE of $1954, \S 1$ (a). However, only $50 \%$ of a net longterm capital gain, as defined in id., $\$ 1222(7)$, is included in taxable income. Id., $\S 1202$. Moreover, the maximum tax on net long-term capital gains is limited to $25 \%$ of the gain. Id., $\$ 1201$ (b).

The first $\$ 25,000$ of a corporation's "ordinary" income is taxed at $30 \%$, and the remainder at 52\%. Id., § 11, 68A STAт. 11 (later amended by Tax Rate Extension Act of 1955,69 Stat. 14). A net long-term capital gain of a corporation is taxed at only $25 \%$. INT. REv. CODE OF 1954, § 1201 (a).

It is usually to a taxpayer's advantage if property disposed of at a gain is classified a capital asset. If, however, a loss has been incurred, the taxpayer will benefit if it is considered an ordinary rather than capital loss. Ordinary losses are fully deductible in computing taxable income. Id., $\$ 165$ (a). See note 8 infra. Capital losses are deductible only to the extent of realized capital gains, $i d$. ., $\$ 1211(\mathrm{a})$, or, for a noncorporate taxpayer, capital gains plus taxable income or $\$ 1,000$, whichever is smaller, $i d$., $\$ 1211(b)$. Under $i d ., \S 1212$, a capital loss not deductible in a given taxable year can be carried over and applied against the net capital gain, as defined in id., $\$ 1222(9)$, in each of the five succeeding taxable years.

2. INT. Rev. CoDE of 1954, §§ 1221(1)-(5) (formerly Int. Rev. Code of 1939, § 117 (a) (1), as amended, 64 Stax. 932 (1950)).

3. INT. REv. CODE of 1954, \& 1221 (2). The exclusionary clause concerning real property was added by the Revenue Act of 1942, $\$ 151$ (a), 56 STAт. 846; the clause concerning depreciable property, by the Revenue Act of 1938, $\S 117$ (a) (1), 52 STAT. 500.

Although real and depreciable property used in trade or business are thus excluded from the statutory definition of a capital asset in $\$ 1221$, the sale or exchange of such property may still give rise to capital gain under INT. REv. CODE of 1954, $\$ 1231$. This section first appeared in the Revenue Act of $1942, \S 151$ (b), 56 STAт. 846. It provides that if, during the taxable year, the gains on the sale, exchange, or involuntary conversion of real or depreciable property used in taxpayer's trade or business and held for more than six months, plus the gains on the involuntary conversion of capital assets held for more than six months, exceed the losses therefrom, the net gain shall be considered a capital gain. However, if such losses exceed such gains, the net loss is an ordinary loss.

4. INr. Rev. CoDE of 1954, § 1221(1). Stock in trade of the taxpayer, or other propcrty of a kind which would properly be included in the inventory of the taxpayer (if on 
personal property 5 -even when acquired and held for business rather than investment purposes-are not expressly covered by any exclusionary clause. And the courts have had considerable difficulty deciding whether the sale of such intangibles by a taxpayer who acquired them incident to his business gives rise to capital or ordinary gains and losses. ${ }^{6}$

Despite an apparent conflict with statutory language, recent cases have generally held that the sale or exchange of intangible assets acquired incident to a business transaction gives rise to ordinary gains and losses. ${ }^{7}$ Courts have adopted different rationales to reach this result. Some courts have considered the loss of value as a business loss, attributable to the sale of a noncapital asset. $^{8}$ These cases have usually fitted the asset within the exclusionary clause of "property held ... primarily for sale to customers in the ordinary course of ... trade or business," despite the fact that taxpayer had held the property "primarily" for purposes other than resale, and had sold it to buyers who were not "customers" of his trade or business. ${ }^{10}$ Some courts have permitted the

hand at the close of the taxable year), were excluded from the term "capital assets" by the original definition of the term in the Revenue Act of 1921, $\S 206$ (a) (6), 42 Star. 233. The Revenue Act of 1924, $\$ 208$ (a) (8), 43 STAт. 263, excluded property held by the taxpayer primarily for sale in the course of his trade or business. The words "to customers" and "ordinary" were added to the latter exclusionary clause by the Revenue Act of 1934, $\S 117$ (b), 48 Stat. 714. See note 28 infra.

5. Accounts or notes receivable acquired in the ordinary course of trade or business as payment for goods or services have been specifically excluded from the definition of a capital asset by INT. Rev. CODE of 1954, $\$ 1221$ (4). Prior to the addition of this exclusionary clause in the 1954 Code, the tax treatment of such notes had presented the courts with considerable difficulty. Compare Rockford Varnish Co., 9 T.C. 171 (1947) (capital loss), with Hercules Motors Corp., 40 B.T.A. 999 (1939) (ordinary loss). The clause excluding notes and accounts receivable will of course be of no help to the courts in the future adjudication of cases to which the 1939 Code is still applicable. This is especially true because Congress did not profess to be codifying case law by this addition to $\$ 1221$. See H.R. REp. No. 1337, 83d Cong., 2d Sess. 82, A273-74 (1954) ; S. Rep. No. 1622, 83d Cong., 2d Sess. 111, 431 (1954).

6. Compare cases cited notes 8,11 infra (ordinary income or loss), with cases cited note 13 infra (capital gain or loss).

7. See, e.g., Tulane Hardware Lumber Co., P-H T.C. Rep. Dec. If 24.129 (1955) (discussing and rationalizing the trend of cases).

8. Charles A. Clark, 19 T.C. 48 (1952) ; Western Wine and Liquor Co., 18 T.C. 1090 (1952); Joe B. Fortson, 47 B.T.A. 158 (1942) ; Hercules Motors Corp., 40 B.T.A. 999 (1939); Gilbert v. Commissioner, 56 F.2d 361 (1st Cir. 1932).

Under INT. Rev. CODE of 1954, $\$ \$ 165$ (a), (c) (1) (formerly Int. Rev. Code of 1939, $\$ \S 23(\mathrm{f}), 23(\mathrm{e})(1), 53$ STAт. 13), a business loss is fully deductible in computing taxable income. But INT. REv. Code of 1954, § 165(f) (formerly Int. Rev. Code of 1939, § 23 (g) (1), 53 Stat. 13) provides that losses from sales or exchanges of capital assets are allowable only as capital losses.

9. INT. Rev. CODE of 1954, $\$ 1221$ (1). See cases cited note 8 supra; Harry Dunitz, 7 T.C. 672 (1946), aff'd per curiam, 167 F.2d 223 (6th Cir. 1948) (gain, rather than loss, from sale of noncapital asset). See note 36 infra.

10. See Commissioner v. The Bagley \& Sewall Co., 221 F.2d 944, 948 (2d Cir. 1955) (dissenting opinion); Western Wine and Liquor Co., 18 T.C. 1090, 1099 (1952) (dissent- 
losses to be fully deducted as "ordinary and necessary" business expenses, ${ }^{11}$ thus avoiding the problem whether the property should be classified as a capital asset under section $1221 .^{12}$ Other courts, however, have been unwilling to depart from a strict interpretation of the statutory language. ${ }^{13}$ Although acknowledging that the property was not held primarily for investment, and would not have been acquired "but for" the taxpayer's business, these courts have stated that the language of the Code compelled them to treat the property as capital assets. ${ }^{14}$

ing opinion). "While it may be contended that each time [taxpayer] ... sold the securities it dealt with a customer, such is not true within a fair reading of the taxing statute." George E. Warren Co. v. United States, 53 F. Supp. 578, 581 (D. Mass. 1944). See also note 14 infra.

Another method adopted by the courts to exclude property connected with business from the statutory definition of a capital asset is to stretch the exclusionary clause concerning property properly includible in inventory. See Corn Products Refining Co. v. Commissioner, 215 F.2d 513 (2d Cir. 1954), aff'd on other grounds, 350 U.S. 46 (1955).

11. E.g., Commissioner v. The Bagley \& Sewall Co., 221. F.2d 944 (2d Cir. 1955) ; Tulane Hardware Lumber Co., P-H T.C. Rep. Dec. II 24.129 (1955) ; Pressed Steel Car Co., 20 T.C. 198 (1953).

In both the Tulane Hardware and Pressed Steel cases, there was no sale or exchange of the securities acquired for business reasons, since they became worthless while held by the taxpayer. INT. REv. CoDE of 1954, \$ $165(\mathrm{~g})$ (1) (formerly Int. Rev. Code of 1939, $\$ 23(g)(2), 53$ STAт. 13) provides that if any security which is a capital asset becomes worthless during the taxable year, the resulting loss shall be treated as a loss from the sale or exchange, on the last day of the taxable year, of a capital asset. Despite this provision, the courts permitted the cost of the worthless securities to be fully deducted as a business expense without deciding whether the securities were outside the statutory definition of a capital asset. Cf. Helvering v. Community Bond \& Mortgage Corp., 74 F.2d 727 (2d Cir. 1935), affirming 27 B.T.A. 480 (1932) (cost of stock acquired for business purposes and possessing no resale value held business expense rather than capital expenditure); Commissioner v. The Hub, Inc., 6\& F.2d 349 (4th Cir. 1934) (same).

12. INT. REv. CODE of 1954, \$162(a) (formerly Int. Rev. Code of $1939, \S 23$ (a) (1) (A), as amended, 66 STar. 443 (1952)) allows "as a deduction [from gross income] all the ordinary and necessary expenses paid or incurred during the taxable year in carrying on any trade or business. ..." Several courts have concluded that the question of what constitutes a business expense can be "determined by business necessity [under $\S 162(a)$ ] without a specific consideration of [\$1221]...." Commissioner v. The Bagley \& Sewall Co., supra note 11, at 947; see other cases cited note 11 supra.

13. Exposition Souvenir Corp. v. Commissioner, 163 F.2d 283 (2d Cir. 1947); Graham Mill \& Elevator Co. v. Thomas, 152 F.2d 564 (5th Cir. 1945) ; Estate of Clarence E. Lehr, 18 T.C. 373 (1952) ; Rockford Varnish Co., 9 T.C. 171 (1947); Logan and Kanawha Coal Co., 5 T.C. 1298 (1945) ; cf. McGhee Upholstery Co., P-H 1954 T.C. Mem. Dec. If 54014 (1953).

14. "The notes were property held by the taxpayer. They were not stock in trade or other inventoriable property, depreciable property, or real property used in the business of the petitioner. . . . Here ... the property came into the hands of the petitioner in the ordinary course of its business and was not acquired to be held as an investment. ... [But] it can not fairly or properly be said that [the notes] . . . were held primarily for sale to customers in the ordinary course of the petitioner's business. It follows that they were capital assets within the statutory definition and the limitation applies. This may be unfortunate, but it is in accordance with our understanding of the law as enacted by Congress." Rockford Varnish Co., supra note 13, at 172-73. 
In the recent case of Corn Products Refining Co. $v$. Commissioner, ${ }^{15}$ the Supreme Court held that both profits and losses ${ }^{16}$ resulting from "hedging" transactions in commodity futures were properly treated as ordinary income and loss. Taxpayer, a corporation engaged in the manufacture and sale of corn products, had systematically purchased corn futures contracts in order to protect its manufacturing profit margin against possible increases in the price of corn. ${ }^{17}$ The futures transactions produced a net loss of $\$ 110,000$ in 1942 , but had produced a net profit of $\$ 680,000$ in $1940 .{ }^{18}$ Taxpayer initially re-

15. 350 U.S. 46 (1955), affirming 215 F.2d 513 (2d Cir. 1954), 16 T.C. 395 (1951).

16. Ibid. The fact that Corn Products involved both gains and losses seems significant. In the past, the cases were concerned with either gain or loss (usually loss), but not both. Thus, it was never perfectly clear whether a holding of "ordinary" loss necessarily required holdings of "ordinary" gain in future cases dealing with similar types of transactions. Moreover, the area of law was further clouded because the Commissioner often took an attitude no less schizophrenic than that of the taxpayer, arguing for "capital" treatment for losses but "ordinary" treatment for gains arising from the same kinds of transactions. See note 45 infra.

17. Under taxpayer's pricing policy, it was obligated to sell its finished products at the contract price or the market price on the date of delivery, whichever was lower. Moreover, its storage facilities were limited. To guard against the repercussions of future increases in the price of corn, its principal raw material, taxpayer purchased corn futures (contracts to buy a stated number of bushels at a stated price during a stated future month) whenever the price appeared favorable. Apparently, taxpayer was operating on the theory that any rise in the price of its raw material would be offset by a concomitant rise in the market value of its holdings in corn futures. Taxpayer took delivery on few of these contracts; it usually sold them unless a corn shortage was imminent. Corn Products Refining Co. v. Commissioner, 350 U.S. $46,48-49$ (1955).

Courts which before the instant case had considered the tax treatment of hedging transactions in commodity futures generally accepted the position of G.C.M. 17322, XV-2 CuM. BuLl. 151 (1936), that losses from so-called "true" hedges were essentially insurance and fully deductible as ordinary and necessary business expenses. Stewart Silk Corp., 9 T.C. 174 (1947) ; Kenneth S. Battelle, 47 B.T.A. 117, 127 (1942); Ben Grote, 41 B.T.A. 247 (1940). This result has now been codified by INT. REv. CoDE of 1954, $\$ 1233$ (a). H.R. Rep. No. 1337, 83d Cong., 2d Sess. A278 (1954) ; S. Rep. No. 1622, 83d Cong., 2d Sess. 437 (1954).

Until Corn Products, however, courts tended to define a "true" hedge narrowly, holding that losses from transactions in commodity futures by a business taxpayer which werc not "true" hedges were deductible only as capital losses. Trenton Cotton Oil Co. v. Commissioner, 147 F.2d 33 (6th Cir. 1945) ; Commissioner v. Farmers \& Ginners Cotton Oil Co., 120 F.2d 772 (5th Cir.), cert. denied, 314 U.S. 683 (1941) ; Estate of Dorothy Makransky, 5 T.C. 397 (1.945), aff'd per curiam, 154 F.2d 59 (3d Cir. 1946). See also Rich \& Rippe, Tax Aspects of Commodity Futures Transactions with a Business Purpose, $2 \mathrm{TAx}$ L. REv. 541 (1947).

In Com Products, taxpayer argued that its transactions in corn futures were not "true" hedges because it was protected only against future increases in the price of corn. Dismissing this contention, the Supreme Court pointed out that "petitioner feared the possibility of a price rise much more than that of a price decline. It therefore purchased partial insurance against its principal risk. ..." Corn Products Refining Co. v. Commissioner, supra, at 51.

18. Corn Products Refining Co. v. Commissioner, supra note 17, at 49.

Taxpayer's large profits in 1940 appear to have been nonrecurrent, attributable to the 
ported these figures as ordinary income and loss, but later contended that they should have been taxed as capital gains and losses. ${ }^{19}$ Taxpayer did not dispute that the futures transactions were an integral part of its trade or business; rather, it insisted that the futures contracts were capital assets as defined in section 1221 and should have been taxed accordingly, whether or not they were acquired for business purposes. ${ }^{20}$

The Supreme Court unanimously held that the hedging transactions were not the type of activity for which Congress intended special capital asset treatment. ${ }^{21}$ The Court argued that the preferential tax treatment provided by the capital assets sections should be applied only when the legislative purpose would thereby be effectuated. ${ }^{22}$ And it stated that the underlying purpose of these sections is to relieve investors from excessive hardships when they convert their investments into cash. ${ }^{23}$ The Court was convinced that taxpayer was not a capital investor seeking to make a profit by trading in corn futures, but a self-insurer seeking to protect its profit margin on the sale of corn products. ${ }^{24}$ The Court conceded that the futures contracts did not come within

outbreak of World War II. See Corn Products Refining Co., 16 T.C. 395, 396-97 (1951). This type of hedging transaction almost invariably results in losses. See cases cited note 17 supra.

19. Corn Products Refining Co. v. Commissioner, 350 U.S. 46, 49 (1955).

20. "Both the Tax Court and the Court of Appeals found petitioner's futures transactions to be an integral part of its business designed to protect its manufacturing operations against a price increase in its principal raw material. . . . Corn Products does not level a direct attack on these two-court findings but insists that its futures were 'property' entitled to capital-asset treatment under $[\$ 1221] \ldots$ and as such were distinct from its manufacturing business." Id. at 50. (Emphasis added.)

21. "We find nothing in this record to support the contention that Corn Products' futures activity was separate and apart from its manufacturing operation. On the contrary, it appears that the transactions were vitally important to the company's business as a form of insurance against increases in the price of raw corn. . . For tax purposes petitioner's purchases have been found to 'constitute an integral part of its manufacturing business...." Id. at $50-51$.

22. Id. at 52 .

23. "Congress intended that profits and losses arising from the every-day operation of a business be considered as ordinary income or loss rather than capital gain or loss. The preferential treatment provided by [the capital assets provisions] . . applies to transactions in property which are not the normal source of business income. It was intended 'to relieve the taxpayer from ... excessive tax burdens on gains resulting from a conversion of capital investments, and to remove the deterrent effect of those burdens on such conversions.' Burnet v. Harmel, 287 U.S., at 106 [1932]. . . ." Corn Products Refining Co. v. Commissioner, 350 U.S. 46, 52 (1955).

24. Id. at 50-51. In concluding that the taxpayer was not acting as a "legitimate capitalist," the Court was influenced by the testimony of taxpayer's own officers that the futures were purchased in order to guarantee a ready supply of corn at a fixed price for future manufacturing requirements.

The Court also found that the taxpayer was not a "speculator," even though its hedging transactions were not "true" hedges. The distinction between investment and speculation is by no means clear-cut. See United States v. Chinook Inv. Co., 136 F.2d 984, 985 (9th Cir. 1943). The Code seeks to separate the investor from the speculator by distinguishing 
any clause excluding property held by the taxpayer from the definition of a capital asset. ${ }^{25}$ But it stated that when property is held incident to a taxpayer's regular business, rather than as an investment, the definition of a capital asset in section 1221 must be narrowly, and the exclusionary clauses broadly, construed..$^{26}$

Corn Products represents a significant change in the judicial application of section 1221. The decision in effect rewrites section 1221, excluding from the definition of "capital assets" all property held, without investment intent, in connection with the taxpayer's business. ${ }^{27}$ This is the first time that property has overtly been excluded from capital asset treatment because of the policy of section 1221 ; in the past, courts applying the section have at least purported to look only at its language without attempting to ascertain the congressional policy behind it. ${ }^{28}$ More important, Corn Products marks the first time that

between "long-term" and "short-term" capital gains. A short-term capital gain is defined as a gain from the sale or exchange of a capital asset held for less than six months. Iivr. REv. CODE of 1954, $\$ 1222(1)$. It is taxed as ordinary income rather than at the preferential rates accorded net long-term capital gains. "It is believed that a holding period of 6 months will be a sufficient deterrent to the speculator as contrasted with the legitimate investor." S. REP. No. 1631, 77th Cong., 2d Sess. 50 (1941). However, the designated holding period does not necessarily effectuate different tax treatment of the "investor" and "speculator" and has been soundly criticized. See Miller, The "Capital Asset Concept: A Critique of Capital Gains Taxation: I, 59 Yale L.J. 837, 838-48 (1950). In this note, the term "investment" is used generally to refer to both "speculative" and "true" investment.

25. "Admittedly, petitioner's corn futures do not come within the literal language of the exclusions set out in that section. They were not stock in trade, actual inventory, property held for sale to customers or depreciable property used in a trade or business." Corn Products Refining Co. v. Commissioner, 350 U.S. 46, 51-52 (1955).

26. "Since this section is an exception from the normal tax requirements of the Internal Revenue Code, the definition of a capital asset must be narrowly applied and its exclusions interpreted broadly.... This Court has always construed narrowly the term 'capital assets' in $[\$ 1221] . . . " I d$. at 52 .

It is not clear whether the Court held: 1) that the futures did not come within the scope of $\S 1221$ at all; 2) that they came within the all-inclusive definition of a capital asset, but were excepted by a specific, though judicially undesignated, exclusionary clause if interpreted broadly; or 3) that they came within the all-inclusive definition, but were excepted from capital assets treatment by a judicially added exclusionary clause.

27. See notes 3-5 supra and accompanying text. See also dissenting opinion of Frank, J., in Commissioner v. The Bagley \& Sewall Co., 221 F.2d 944, 948 (2d Cir. 1955) : "From 'capital assets' [\$1221(2)] ... excepts 'real property'-no other-if 'used in the trade or business of the taxpayer.' My colleagues, in effect, treat that clause as if it read any property used in the trade or business of the taxpayer."

28. See Miller, The 'Capital Asset' Concept: A Critique of Capital Gains Taxalion: II, 59 YALE L.J. 1057, 1084-86 (1950). Courts have, of course, sometimes stretched the language of the exclusionary clauses to avoid treating as a capital asset property held in connection with taxpayer's business. See cases cited notes $8-10$ supra. But these courts still professed to be applying the statutory language as written by Congress; they did not justify their broad construction of the exclusionary clauses in terms of policy considerations.

Prior judicial application of the "to customers" phrase of the "trade or business" ex:clusionary clause, INT. REv. CODE of 1954, $\$ 1221$ (1), exemplifies the tendency of the courts 
the Supreme Court has unequivocally stated that investment is the policy of the section. ${ }^{20}$ The decision could be limited to hedging transactions. However, the fact that the Supreme Court chose to affirm the Second Circuit's decision on a different, nonstatutory rationale that was broader than the case required indicates that the Court did not intend the decision to be so limited. ${ }^{30}$

The Corn Products approach to section 1221 constitutes an important beginning toward making sense out of the capital assets sections of the Code. It might be argued that the Court, believing that it could effectuate the policy of capital assets treatment more successfully by disregarding the explicit language chosen by Congress, engaged to an unwarranted extent in judicial legislation. ${ }^{31}$ Nevertheless, the exceptional tax treatment given to capital assets must be supported, if at all, on an investment-business rationale. ${ }^{32}$ And the fact is that Congress has never been able successfully to define a "capital asset." Having initially designated all property as capital assets, Congress has proceeded to limit this definition by piecemeal enactment of exclusionary clauses. ${ }^{33}$ As a

to look only at the language rather than the policy of the capital assets sections. The words "to customers" were added to the clause by the Revenue Act of 1934, $\$ 117$ (b), 48 STAт. 714. The change was made to prevent professional stock market speculators from deducting losses on the sale of securities from ordinary income. S. REP. No. 558, 73d Cong., 2d Sess. 12 (1934); Reprart of Conference Committee on H.R. 7835, H.R. REP. No. 1385, 73d Cong., 2d Sess. 22 (1934). Despite the congressional policy motivating the change in wording, courts have frequently maintained that the "to customers" phrase prevented taxpayers who were not in the securities business from deducting in full losses on the sale of securities acquired for business reasons. See cases cited notes 13-14 supra; Miller, The 'Capital Asset' Concept: A Critique of Capital Gains Taxation: I, 59 Yale L.J. 837, 874-77 (1950).

29. Cf. Burnet v. Harmel, 287 U.S. 103, 106 (1932). The Harmel decision is, however, at best equivocal.

30. To avoid creating a "judge-made exception" to the statutory definition of a capital asset, the Second Circuit had held that the futures contracts were "part of the inventory purchase system which is utilized solely for the purpose of stabilizing inventory cost" and accordingly came within the inventory exclusionary clause. Corn Products Refining Co. v. Commissioner, 215 F.2d 513, 516 (2d Cir. 1954). But see Estate of Dorothy Makransky, 5 T.C. $397,411-12$ (1945), aff'd per curiam, 154 F.2d 59 (3d Cir. 1946). This categorization, at least functionally, seems highly tenable. Since the Supreme Court accepted the finding of the lower court that the dealings in commodity futures were an integral part of the taxpayer's business designed to stabilize inventory cost, it could very easily have adopted the rationale of the Second Circuit.

31. Corn Products is a significant deviation from the traditional judicial rule of interpreting tax statutes literally. See, e.g., Crooks v. Harrelson, 282 U.S. 55, 61 (1930); Masonite Corp. v. Fly, 194 F.2d 257, 261 (5th Cir. 1952) ; Forstmann v. Rogers, 128 F.2d 126, 129 (3d Cir. 1942) ; Minnesota Tea Co. v. Commissioner, 76 F.2d 797, 799 (Sth Cir.), aff'd, 296 U.S. 378 (1935).

32. For discussion and evaluation of the "investment" rationale underlying capital assets treatment, see, e.g., Seltzer, The Nature and Tax Treatarent of Capital Gains and Lasses 3-4, 48-49, 212-13, $282-89$ (1951) ; U.S. Treasury Dep'r, Federal Income Tas: Treataient of Capital Gains and Losses 13, 21-22, 52-53; Miller, The 'Capital Assel' Concept: A Critique of Capital Gains Taxation: II, 59 YALE L.J. 1057 (1950); cf. Kich \& Rippe, supra note 17, at 559-64.

33. The term "capital assets" was first defined by Congress in the Revenue Act of 
result, the capital assets provisions now constitute a compartmentalized series of "pigeonholes," lacking a clear statement of standards or policy by which to determine their applicability to particular fact situations. ${ }^{34}$ The Court's attempt to establish a policy-oriented approach therefore seems warranted.

The Corn Products approach will, however, create serious administrative difficulties for the Commissioner. For if securities and similar property are acquired for business purposes, and sold at a loss, the taxpayer will emphasize the underlying business context when preparing his tax returns, and will thus obtain a full "business" deduction. ${ }^{35}$ But if the property is sold at a profit, some taxpayers are likely to report the increment as capital gain without mentioning the surrounding circumstances. Thus, on the strength of the infor-

1921, § 206(a) (6), 42 STAT. 233. The definition then given was "property acquired and held by the taxpayer for profit or investment... (whether or not connected with his trade or business)." But the term did not include "property held for the personal use or consumption of the taxpayer or his family," stock in trade, or inventory. Ibid. This definition was modified by the Revenue Act of 1924, § 208(a) (8), 43 Stat. 263. A capital asset was there defined as "property held by the taxpayer ... (whether or not connected with his trade or business)" and not including stock in trade, inventory or property held primarily for sale in the course of business. The change was made to permit individuals to realize capital gains on the sale of residences and other property not purchased for profit. SELTZER, op. cit. supra note 32, at 20.

From 1924 until the present, Congress has added exclusionary clauses to the all-inclusive definition of a capital asset, as it came to believe that designated types of property were more appropriately treated as noncapital assets. The "to customers" phrase was added in 1934. See note 4 st pra. Depreciable business property was excluded in 1938; real business property, in 1942. See note 3 supra. Government obligations issued on a discount basis and payable without interest at a fixed maturity date were excluded by the Revenue Act of 1941, \& 115(b), 55 Stat. 698 (now Int. Rev. Code of 1954, \$ 1221(5)). Copyrights, literary, musical and artistic compositions were excluded by the Revenue Act of 1950, $\$ 210$ (a), 64 Stat. 933 (now Int. Rev. Code of 1954, \$ 1221(3)). Accounts and notes receivable were excluded in 1954 . See note 5 supra. Under the 1954 Code, it is clear that hedging transactions in commodity futures give rise to ordinary income and loss. See note 17 supra.

The explanation for the omission of an exclusionary clause concerning stacks, bonds, and similar intangible assets acquired for business purposes is probably that this type of property is usually held for investment or speculative purposes, and seldom acquired incident to business transactions. Seventy-five per cent of capital gains and losses are derived from transactions in securities. U.S. TREASURY DEP'T, op. cit. supra note 32, at 10. Securities held by dealers for sale to customers in the ordinary course of business are of course excepted by INT. Rev. CODE of 1954, § 1221(1). See also id., § 1236, discussed at note 46 infra.

34. See Miller, The 'Capital Asset' Concept: A Critique of Capital Gains Taxation: II, 59 Y ALE L.J. 1057, 1084-86 (1950). Compare Commissioner v. The Bagley \& Sewall Co., 221 F.2d 944, 946-47 (2d Cir. 1955) (stating that there was no need to reconcile a classification of "business expense" with the capital assets sections).

35. A recent tax service bulletin, issued previous to Corn Products, noted the tendency of some courts to allow a full deduction for losses on the sale of securities acquired for a business purpose, and suggested that prior tax returns be reviewed and refund claims filed if such losses were reported as capital losses. Research Institute of America, Taxation Report, Oct. 6, 1955, p. 147. 
mation contained in such returns, the Commissioner will not be able to differentiate between securities transactions giving rise to "investment" income and those which should give rise to "business" income. ${ }^{36}$ As a result, he will be forced to investigate the circumstances surrounding the acquisition of all securities which a business taxpayer has reported as giving rise to capital gain. And since all reported capital gains cannot be scrutinized, some taxpayers will be able to obtain capital gains on securities which could have been disposed of at ordinary losses. Moreover, this result does not presuppose bad faith on the part of the taxpayer; security-type property may often be acquired for both "business" and "investment" purposes. ${ }^{37}$

Furthermore, the Supreme Court's decision establishes only the broadest outlines of distinction between "business" and "investment" income or loss. It does not provide workable standards by which the lower courts may determine into which category a marginal transaction should be placed. Prior judicial experience indicates this will be no easy task..$^{38}$ Courts will have to determine, long after the event, what the taxpayer's "intent" was in acquiring and holding the property. Since the taxpayer's testimony as to his subjective intent cannot be made controlling," an "objective" standard will be required.

36. In only one case has the Commissioner contended that a profit on a securities sale reported as a capital gain should be considered an ordinary gain because the securities were acquired as an incident to the taxpayer's regular business. In Harry Dunitz, 7 T.C. 672 (1946), aff'd per curiam, $167 \mathrm{~F} .2 \mathrm{~d} 223$ (6th Cir. 1948), the taxpayer repurchased at large discounts and then sold to a controlled corporation bonds which he had originally executed to finance construction of an apartment building. The court held that the profit on the resale was ordinary income. Since the bond transaction was an "essential and integral part" of the taspayer's business of managing buildings, the bonds were considered to be held primarily for sale to customers in the ordinary course of business. The fact that the securities on which the gain was reported were obligations of the taxpayer probably induced the Commissioner to scrutinize the circumstances of the transaction. The dearth of cases in which the Commissioner has disputed the taxpayer's classification on these grounds would seem to indicate that review of tax returns rarely discloses whether securities giving rise to a reported capital gain were originally acquired for a business purpose. The validity of this conclusion may, however, be weakened by inability to ascertain the frequency with which such classifications are compromised.

This difficulty might be minimized by requiring the taxpayer to report any business context in which he acquired securities the sale of which he is reporting as capital gain. See note 49 infra.

37. See note 39 infra; text at notes $43-44$ infra.

Cf. Seaboard Finance Co. v. Commissioner, 225 F.2d 808 (9th Cir. 1955) (foreign currency transaction connected with taxpayer's business probably motivated by both "business" and "speculative" considerations).

38. Consider, e.g., the difficulty courts have had distinguishing real estate "dealers" from real estate "investors." Compare Chandler v. United States, 226 F.2d 403 (7th Cir. 1955), with Mauldin v. Commissioner, 195 F.2d 714 (10th Cir. 1952). See Fink, 'Dealing' in Real Estate, 2 TAX L. Rev. 111 (1946) (collecting citations).

39. In Corn Products, taxpayer's officers made disserving statements when they testified that the hedging transactions were undertaken solely for business reasons. See note 24 suffra. In the vast majority of cases taxpayer's testimony of his subjective intent will be self-serving. Moreaver, such testimony would not necessarily be in bad faith. For if a 
Any attempt to determine the taxpayer's intent from the circumstances surrounding the transaction will raise serious problems of delineation. In Corn Products, the taxpayer had systematically purchased and sold futures over a ten year period ${ }^{40}$ in order to stabilize costs. It was not difficult to classify the gains and losses resulting from these sales as part of the "every-day operation" of taxpayer's business. ${ }^{41}$ But quantitative repetition as such is not a satisfactory standard. For a taxpayer may make a single purchase of intangible property to accomplish a specific business goal. For example, he may have to purchase securities issued by a supplier in order to ensure a source of the product in which he deals. ${ }^{42}$ And if the courts interpret Corn Products to require a repeated pattern of dealings, the taxpayer would be unable to deduct bona fide but nonrecurring business expenses from his business income.

On the other hand, the courts should not permit the taxpayer to obtain fully deductible business losses whenever he acquires securities in order to accomplish a business purpose. Use of this criterion would permit businessmen to write off speculative "investment" losses against "business" income. For, even though an acquisition is motivated by business needs, it does not necessarily follow that the securities continue to be held for business purposes after acquisition. Thus, the taxpayer who acquired securities to obtain a source of supply may not have had to keep the securities to obtain future supply; the supplier generally would not require the customer to retain the securities, once he has bought them. ${ }^{43}$ And the taxpayer may thereafter hold the securities in order to recoup some of the expense of purchasing them, through marliet accretion, or to maintain "good will" with the supplier.44 In neither instance should further

securities transaction resulted in a profit, taxpayer might very well feel that his motive had been "primarily" investment; on the other hand, if a loss was incurred, he would probably conclude that the transaction had been undertaken "primarily" for business reasons.

40. Corn Products Refining Co., 16 T.C. 395, 396 (1951).

41. See note 23 sipra.

42. See Hogg v. Allen, 105 F. Supp. 12, 18 (M.D. Ga. 1952), aff'd in part sub nom. Edwards v. Hogg, 214 F.2d 640, 642 (5th Cir. 1954); Tulane Hardware Lumber Co., P-H T.C. Rep. Dec. I 24.129 (1955); McGhee Upholstery Co., P-H 1954 T.C. Mem. Dec. If 54014 (1953) ; Charles A. Clark, 19 T.C. 48 (1952) ; Western Wine and Liquor Co., 18 T.C. 1090 (1952); Logan and Kanawha Coal Co., 5 T.C. 1298 (1945) ; cf. Exposition Souvenir Corp. v. Commissioner, 163 F.2d 283 (2d Cir. 1947).

43. See, e.g., McGhee Upholstery Co., supra note 42; Charles A. Clark, supra note 42; Western Wine and Liquor Co., supra note 42 . In these cases the taxpayer was required only to purchase securities in order to obtain merchandise; he was not compelled to hold them for any minimum period.

44. Frequently businessmen who have acquired securities incident to business transactions hold them for a substantial time after acquisition. Sometimes the securities must be held in order to accomplish the business purpose for which they were originally acquired. See Commissioner v. The Bagley \& Sewall Co., 221 F.2d 944 (2d Cir. 1955) (securities placed in escrow to assure performance of manufacturing contract). Sometimes the securities are held because no purchaser can be found for them. See Joe B. Fortson, 47 B.T.A. 158 (1942). Often the motive for retention is unclear. In determining the tax treatment of these securities, the courts have tended to stress the reason for acquisition rather than 
losses in market value be deductible from business earnings. Plainly, this standard is also defective. Moreover, to the extent that different courts apply different standards-or apply similar standards differently-the tax burden will fall unequally upon taxpayers in like circumstances. ${ }^{45}$

Nevertheless, most of the problems of classification created by Corn Products can be satisfactorily resolved if the Commissioner will promulgate an appropriate regulation. This regulation should provide that: any security (or similar intangible asset) acquired by a taxpayer (other than a dealer in securities) ${ }^{46}$ will be treated as an investment unless, within thirty days after the date of acquisition, the Commissioner is notified that designated property of stated value has been acquired and is being held for specified business purposes. The Commissioner and the courts should then treat property so registered as business property, ${ }^{47}$ giving rise to ordinary income or loss, unless taxpayer's

the reason for retention. Thus, in Gilbert v. Commissioner, 56 F.2d 361 (1st Cir. 1932), the loss incurred by a contractor on the sale of stock acquired from a corporation as payment for construction work was held fully deductible as an ordinary loss, even though the taxpayer had held the securities for over two years before selling them. See also Tulane Hardware Lumber Co., P-H T.C. Rep. Dec. If 24.129 (1955) (debentures purchased to obtain source of supply held for five years, at which time they became worthless because of failure of issuing company) ; Logan and Kanawha Coal Co., 5 T.C. 1298 (1945) (stock acquired to secure source of supply held for four years). But cf. Western Wine and Liquor Co., 18 T.C. 1090 (1952) (stock acquired to obtain source of supply held less than two months).

In cases where securities acquired incident to business transactions are not immediately sold, the proper tax treatment under the Corn Products doctrine would appear to be as follows: The court (preferably the Tax Court) should ascertain whether the securities were sold as soon as the original business reason for acquisition was satisfied. If not, the court should determine the fair market value of the securities at the earliest date they could have been sold, and the difference between this value and taxpayer's cost should be given "business" income treatment.

If the securities were held past the earliest disposal date in the hope of market appreciation, any subsequent increase or decrease in market value should be treated as capital gain or loss. But if the securities were held to maintain favorable relations with the party issuing them, it would seem that any decrease in value after the earliest disposal date should be considered a capital expenditure for the promotion of good will. Accordingly, it would not be deductible as an ordinary or capital loss; it would instead be capitalized as part of the cost basis of good will. INT. REv. CODE OF 1954, § 263(a) (1); Welch v. Helvering, 290 U.S. 111 (1933).

For a more practicable alternative, see notes $46-48$ infra and accompanying text.

45. Furthermore, the Commissioner may take inconsistent positions in various cases, depending upon whether the property in question was sold at a gain or loss. See United States v. Chinook Inv. Co., 136 F.2d 984, 985 (9th Cir. 1943).

46. The transactions of a securities dealer are divided into "business" and "investment" categories by INT. REv. CODE of 1954, $\$ 1236$. This section provides that a gain by a securities dealer from the sale of a security will not be considered a capital gain unless, within thirty days after the date of acquisition, the security is clearly identified as being held for investment, and is not later held for sale to customers. Id., $\$ 1236$ (a). Moreover, if any security is so identified, any loss on its sale is a capital loss. Id., $\$ 1236(\mathrm{~b})$.

47. The proposed regulation should specify that failure to comply with the notification procedure constitutes either a conclusive or a rebuttable presumption that securities 
alleged business purpose is patently unrealistic and until taxpayer notifies the Commissioner that he wishes to hold the property for investment. ${ }^{48}$ Such a procedure would simplify administrative review of tax returns; ${ }^{40}$ it would minimize the danger of inconsistent tax treatment by eliminating the problem of retrospective judicial inquiry into taxpayer's intent $;^{30}$ and it would require taxpayer to elect the tax treatment he prefers, and the grounds upon which he believes he is entitled to it, before he knows whether there will be gain or loss. So long as Congress chooses to distinguish between the gain or loss resulting from the sale of "capital" and "business" assets, a regulation similar to the one suggested will be necessary to enable the courts and the Commissioner efficiently to carry out the policies implicit in the Tax Code and elucidated by the Supreme Court in the Corn Products case.

acquired by the taxpayer have been held as an investment. Preferably, the presumption should be conclusive, but such a provision might run into constitutional difficulties. $C f$. the "Clifford Regulation," U.S. Treas. Reg. 118, § 39.22(a)-21 (1945), held unconstitutional in part in Commissioner v. Clark, 202 F.2d 94 (7th Cir. 1953).

48. A taxpayer who has previously elected to receive ordinary income treatment on securities acquired incident to a business transaction might desire to hold them as an investment after the business purpose has been fulfilled. Accordingly, the Commissioner might provide that such a taxpayer could report as ordinary income the difference between the cost of the securities and their fair market value at the date they are held as an investment. $C f$. note 44 supra. The burden would be on the taxpayer to establish the fair market value on that date. Any future disposition of the securities would then give rise to capital gain or loss, with the fair market value of the investment date as the basis. Such a procedure would enable the taxpayer to save the brokerage fees incurred in selling and then purchasing identical securities.

49. See notes 35-37 supra and accompanying text.

Even if the suggested regulation is not adopted, the Commissioner could minimize the administrative difficulties created by Com Products by requiring additional information in tax returns. Taxpayers should be instructed to designate whether the acquisition of any securities giving rise to a reported capital gain was in any way connected with their trade or business. The Commissioner would thus be able to identify more readily securities transactions which, under Corn Products, should result in ordinary rather than capital gain.

50. See notes $38-45$ sitpra and accompanying text. 